\title{
ANALISIS KEMATANGAN EMOSIONAL TERHADAP HASIL BELAJAR PENJAS KELAS XI DIMASA PANDEMI COVID-19
}

\author{
Wahyu Joko Santiko ${ }^{1)}$
}

${ }^{1}$ FPIPSKR, Universitas PGRIS Semarang

Email: wahyujokosantiko@gmail.com

\begin{tabular}{l}
\hline Artikel Info \\
\hline \\
Koresponden penulis : \\
Wahyu Joko Santiko \\
Email : wahyujokosantiko@gmail.com
\end{tabular}

Diterima 9 November 2021

Direview 18 Januari 2022

Disetujui 29 Januari 2022

Dipublikasi 31 Januari 2022
Kata Kunci: Kematangan Emosional, Hasil Belajar, Covid-19

\begin{abstract}
Abstrak
Tujuan pada penelitian ini adalah untuk mengetahui apakah kematangan emosional berpengaruh terhadap hasil belajar pendidikan jasmani pada kelas XI SMA N 2 Pati dimasa pandemi. Penelitian ini merupakan penelitian deskriptif kualitatif. Subjek atau informan adalah siswa kelas XI SMA N 2 Pati, untuk proses pengumpulan data dilakukan dengan sistem wawancara, observasi serta ditunjang dengan dokumentasi. Adapun teknik analisis data dilakukan melalui reduksi data, penyajian data serta penarika kesimpulan. Dimana hasil dari penelitian ini menunjukkan bahwa tingkat kematangan emosioanal seorang siswa terbukti berpengaruh terhadap hasil belajar pendidikan jasmani siswa kelas XI SMA N 2 Pati dimasa pandemi saat ini. Hasil lain juga menunjukkan bahwasannya siswa yang mempunyai kematangan emosional tinggi, dimana saat melaksanakan penilaian, baik penilaian Afektif, Kognitif dan Psikomotor semuanya memperoleh nilai diatas rata-rata.
\end{abstract}

\begin{abstract}
Aim in this study was to determine whether emotional maturity had an effect on physical education learning outcomes in class XI of SMA N 2 Pati during the pandemic. This research is a qualitative descriptive study. the subject or informant is a class XI student of SMA N 2 Pati, for the data collection process is carried out by an interview system, observation and supported by documentation. as for the data analysis technique is done through data reduction, data presentation and drawing conclusions. where the results of this study indicate that the level of emotional maturity of a student is proven to have an effect on physical education learning outcomes for class XI students of SMA N 2 Pati during the current pandemic. other results also show that students who have high emotional maturity, where when carrying out assessments, both affective, cognitive and psychomotor assessments all get above average scores.
\end{abstract}

Keywords: Emotional Maturity, Learning Outcomes, Covid-19 


\section{PENDAHULUAN}

Pendidikan jasmani adalah bentuk pembelajaran yang tidak hanya berfokus terhadap segi pengembangan pengetahuan ataupun keterampilan yang berkaitan dengan aktivitas jasmani siswa saja tetapi juga berfokus terhadap perkembangan karakter dan sebagainya, dimana pendidikan jasmani mampu membentuk perkembangan karakter siswa atau emosional siswa, dimana karakter atau emosional siswa ini sangat berperan penting terhadap proses belajar dan hasil belajar siswa didalam sekolah ataupun setelah lulus dari sekolah nantinya. Kematangan emosional setiap siswa pasti berbeda-beda, apalagi bagi siswa SMA yang disisi lain mereka juga sudah mulai memasuki masa remaja dengan kondisi atau keadaan emosi yang masih belum stabil atau masih labil sehinga pasti akan berdampak terhadap emosionalnya. Ditambah lagi dengan situasi dan kondisi saat ini yang dimana pembelajaran dilaksanakan secara daring dikarenakan pandemi Covid-19 yang sedang terjadi sehingga hal ini dapat berpengaruh terhadap kondisi emosional setiap siswa tersebut. Melalui penjelasan diatas dimana peneliti tertarik untuk meneliti mengenai analisis kematangan emosional terhadap hasil belajar pendidikan jasmani pada siswa kelas XI SMA N 2 Pati dimasa pandemi Covid-19, dimana realita yang terjadi yaitu terdapat berbagai masalah yang terjadi terutama kelas XI, dimana respon dan tanggung jawab mereka terhadap kondisi seperti tugas dan lain-lain sangat rendah dan penerimaan siswa terhadap orang lain juga rendah. Hal ini bisa saja terjadi dikarenakan pendidikan karakter yang ditanamkan dari guru belum sepenuhnya masuk kepada siswa. Sehingga timbullah kondisi seperti tersebut.

\section{METODE PENELITIAN}

Jenis penelitian ini adalah deskriptif dengan pendekatan kualitatif dengan metode wawancara yang dilakukan melalui ZOOM. Objek Adapun penelitian ini dilakukan di SMA N 2 PATI, dimana subjek penelitian adalah siswa kelas XI berjumlah 5 siswa dari jumlah populasi sebanyak 408 siswa. Adapun teknik sampling yang digunakan ialah random sampling (sampling acak). Proses pengumpulan data melalui metode wawancara, observasi serta dokumentasi. Peneliti menggunakan instrumen penelitian terdahulu yaitu dari Skripsi Mariana Panji Ramadan tahun 2013 yang kemudian peneliti kembangkan lagi untuk item pertanyaannya yang sebelumnya berbentuk kuanti menjadi kuali, untuk item pertanyaan berjumlah 20 terdiri dari 4 indikator, dimana setiap indikator terdiri dari 5 item pertanyaan. Kemudian setelah dilakukan uji validitas 20 pertanyaan lolos semua sehingga bisa dipakai semua. Sedangkan untuk teknik analisis data pada penelitian ini dengan melalui 3 tahap yaitu 
http://jurnal.unipasby.ac.id/index.php/stand/about/submissions jurnal.stand@unipasby.ac.id

reduksi data, penyajian data serta penarikan kesimpulan.

\section{HASIL DAN PEMBAHASAN}

Penelitian ini bertujuan untuk mengetahui apakah tingkat kematangan emosional berpengaruh pada hasil belajar pendidikan jasmani siswa kelas XI SMA N 2 Pati di masa pandemi Covid-19. Data hasil tes kematangan emosional setiap siswa berbeda atau tidak sama, dimana siswa memiliki perbedaan baik kelebihan dan kekurangan pada indikator kematangan emosional yang berbeda - beda. Pada penelitian ini subjek berjumlah 5 siswa yang terdiri dari 3 siswa IPA dan 2 siswa IPS, dalam menentukan subjek tersebut dilakukan dengan metode Random Sampling ( sampling acak). Semua siswa tersebut menjalani tes kematangan emosioanal guna mengetahui tingkat kematangan emosionalnya. Hasil dari tes kematangan emosional menunjukkan bahwa 5 siswa tersebut memiliki kematangan emosional yang tinggi. Kemudian selanjutnya siswa melakukan penilaian yang meliputi penilaian kognitif, afektif dan psikomotor pada materi olahraga tertentu, dan hasilnya ke-5 siswa tersebut yang memiliki kematangan emosional tinggi mendapatkan nilai diatas KKM dari setiap aspek penilaian ( kognitif, afektif dan psikomotor). Dari hasil penelitian disimpulkan bahwa kematangan emosional seorang siswa terbukti berpengaruh pada hasil belajar pendidikan jasmani kelas XI SMA N 2 Pati di masa pandemi Covid_19 saat ini.

\section{KESIMPULAN}

Berdasarkan hasil penelitian disimpulkan bahwa kematangan emosional seorang siswa terbukti berpengaruh terhadap proses dan hasil belajar pendidikan jasmani siswa kelas XI SMA N 2 Pati di masa pandemi saat ini. Dimana hasil penelitian membuktikan bahwa seluruh siswa yang memiliki kematangan emosioanal tinggi, dimana saat melaksanakan penilaian, baik penilaian Afektif, Kognitif dan Psikomotor semuanya mendapatkan nilai diatas KKM.

\section{REFERENSI}

Sugiyono. (2017). Metode Penelitian

Kualitatif, Kuantitatif dan $R \& D$. Bandung: Alfabeta.

La Kahija, Y.F. (2017). Penelitian Fenomenologis. Yogyakarta: Kanisius.

Pratama, N.Y dan Maftukin Hudah. (2020).

"Pendekatan Permainan Outbound Sirkuit

Game Dalam Meningkatkan Kematangan

Emosional Dan Spitual Melalui Pembelajaran Penjas Pada Siswa SMP N 1Sumowono". Journal Of Sport Coaching and Physical Education. 5 (1) 8-13.

Agustina, Inayah. (2020). Strategi Pengembangan Rainbow Rafting Untuk Meningkatkan Potensi Sport Tourism Kecamatan Randudongkal Kabupaten Pemalang. Skripsi. Semarang: Universitas PGRI Semarang. 


\begin{tabular}{|c|c|}
\hline Unipa Surabaya & Journal STAND: Sports and Development \\
http://jurnal.unipasby.ac.id/index.php/stand/about/submissions \\
jurnal.stand@unipasby.ac.id
\end{tabular}

Naimah, D.M. (2015). Pengertian,

Kematangan, Emosi, Ciri-Ciri-Cara,

Mencapai Faktor, Yang, Mempengaruhi,

Aspek. Diambil dari http://etheses.uin-

malang.ac.id/773/6/10410186\%20Bab\%2

02.pdf. Diakses 15 Desember 2020. 